\title{
Studies on the Value, Function and Realization of Deng Xiaoping's Social Justice Thought
}

\author{
Ying Wang \\ Jilin Agricultural University, Changchun 130118, China
}

Keywords: Deng Xiaoping; social justice; harmonious society.

\begin{abstract}
With the development of socialist modernization, more and more people realize the importance of social justice. As the chief architect of reform and opening up and socialist modernization, Deng Xiaoping made a lot of brilliant and in-depth discussions on social justice thought. Therefore, in the current context of the gap between the rich and the poor, it has important theoretical significance and practical value to review Deng Xiaoping's social justice thought. In this paper, firstly, we define the concept of Deng Xiaoping's thoughts of social justice theory, analyze the theoretical sources of Deng Xiaoping's social justice thought, and put forward that Deng Xiaoping's social justice thought is the inheritance and development of Marxist-Leninist and Mao Zedong's thoughts in social justice. On this basis, we analyze the background of Deng Xiaoping's social justice thought. Secondly, we analyze the value and function of Deng Xiaoping's social justice thought, as well as analyzing the challenges and difficulties of Deng Xiaoping's social justice thought. Finally, we further point out the realization path of Deng Xiaoping's social justice thought.
\end{abstract}

\section{Introduction}

Since the reform and opening up, peace and development have become the theme of the times, and Deng Xiaoping's social justice thought is derived from the theme of peace and development [10]. In the great tide of world history, every era of history has the main contradiction and the basic task of the main contradiction. Under certain historical conditions, the main problem that needs to be solved in the development of world history is the theme of this historical era [8]. As the main contradictions in the history of the world continue to change, the theme of the times is constantly advancing with the times. Since the reform and opening up, China has been in an era of peace and development in terms of the world's major trends and backgrounds. China needs the world more than ever before to develop itself and vice versa. There is no doubt that peace and development are the theme of the times [9]. China's reform and opening up also conform to the theme of world peace and development.

Since the Second World War, the world political pattern has been basically established. Peace and development is a common theme in the world between developed and developing countries [7]. Historical development has proved that the modernization tide is enormous and powerful, that those who go with it will prosper while those who go against it will perish. We must follow the theme of peace and development. Peace and development are not isolated but complementary [5]. World peace is a prerequisite for world development, and world development has become an important foundation for world peace. Therefore, the theme of the present age is made up of peace and development. In the context of the world's great trends and times, peace and development are the themes of the times [11]. However, the issue of peace and development is not a complete solution to the whole world in this period, and the local conflicts still plague the peace and development of the world from time to time. Based on the above understanding, Deng Xiaoping pointed out: "Now the real big problem in the world, one is peace, and the other is economic or development"[1]. Therefore, we should focus on economic construction and vigorously develop productive forces. Finally, in the process of promoting social fairness and justice, we realize the great rejuvenation of the Chinese nation.

Thus, it can be seen that the era of the formation and development of social justice is also the era of peace and development. To comprehensively and profoundly understand the scientific connotation of 
Deng Xiaoping's social justice thought, it is necessary to understand the background of the generation and development of this thought.

\section{The value and function of Deng Xiaoping's social justice thought}

As we all know, social justice is the eternal pursuit of human development and social progress. Since the reform and opening up, social justice has become an increasingly important issue for the party and the state. On the one hand, Deng Xiaoping's social justice thought is based on the theoretical innovation of this long - standing social justice thought, and on the other hand, it is based on the practice of China's reform and opening - up party and the state to promote social justice. Deng Xiaoping's social justice thought not only has important theoretical value, but also has important practical function.

As a crucial theoretical composition of Deng Xiaoping 's theory, Deng Xiaoping' s social justice thought has important theoretical value in promoting the construction of socialist harmonious society, deepening the understanding of the essence of socialism and promoting the realization of social fairness and justice. It plays a very important guiding role in the socialist modernization drive.

To recognize the essence of socialism, we must first clear that China is in the primary stage of socialism. Systematically and comprehensively study Deng Xiaoping's social justice thought, it can further deepen the understanding of the essence of socialism. This means that China is already a socialist country. China's socialism is still in the socialist underdevelopment stage, that is, the primary stage of socialism. The first level is from the nature level, the nature of Chinese society is already socialism, and socialism is necessary from the system to protect the people masters. Another level is from the perspective of productivity, China's productivity level is not developed, and it has not yet reached the requirements of the advanced stage of socialism, so China will be long in the primary stage of socialism.

On the basis of determining China's long-term primary stage of socialism, Deng Xiaoping put forward the essence of socialism in the South talks: "Emancipate the productive forces, develop productive forces, eliminate exploitation, eliminate polarization, and finally achieve common prosperity"[2]. This is clearly stated, because China is still in the primary stage of socialism, to further consolidate and develop socialism with Chinese characteristics, it is necessary to complete the two tasks: On the one hand, the liberation and development of productive forces, from the material level to solve the problem of productivity in the primary stage of socialism. Since China will remain in the primary stage of socialism for a long time, then the main contradiction in the primary stage of socialism will be the contradiction between the growing material and cultural needs of the people and the backward social production. Therefore, as long as we are still in the primary stage of socialism, our fundamental task is to develop the productive forces with economic construction as the center, and gradually meet the people's growing material and cultural needs through the continuous development of productive forces. This means that poverty is not socialism, but also as a socialist country, China is absolutely not allowed. Socialism is to eliminate poverty and backwardness, and socialism is to show more advanced than the capitalist level of productivity. There is no doubt that, although China will remain in the early stages of socialism, the level of productivity development in China's socialist system in recent decades has been recognized around the world. Therefore, we must always adhere to the economic construction as the center, vigorously develop the productive forces, and further demonstrate the superiority of the socialist system.

Deng Xiaoping's social justice thought not only has important theoretical significance and value, but also plays an important role in the practice process. However, it still encounters some theoretical challenges and realistic doubts. By clarifying the challenges and doubts that Deng Xiaoping's social justice thought faces in theory, it is possible to further strengthen the understanding of Deng Xiaoping's social justice thought.

Deng Xiaoping's social justice thought encountered some misunderstanding and misreading in the course of practice. These remarks are too radical or one-sided, and cannot really grasp the inner spirit 
of Deng Xiaoping's social justice. The more representative remarks that denigrate Deng Xiaoping's social justice thoughts include "the theory of the first rich theory", "the theory of capitalism with Chinese characteristics" and "departure from Mao Zedong Thought". In order to better explain and understand Deng Xiaoping's social justice, we need to refute these erroneous remarks and clarify the confusion of Deng Xiaoping's social justice thinking. First, refute the theory of "first rich theory". Poverty is not socialism, and socialism is to show the advantages of development and long-term development prospects than capitalism. At present, the reality of the widening gap between the rich and the poor does exist. However, we cannot deny Deng Xiaoping's social justice thought completely because of the temporary phenomenon in the development process of widening the gap between rich and poor. We emphasize that the theory of the first rich is the pursuit of common prosperity for the pursuit of the first rich theory, rather than only stressed the first rich and ignored the ultimate goal of the total wealth. Second, refute the "Chinese characteristics of capitalism". The Chinese characteristics of socialism as described in Chinese characteristics of capitalism, which is obviously wrong. Deng Xiaoping has clearly pointed out that the reason why China is a socialist system, on the one hand, we must adhere to public ownership, and on the other hand, we insist on common prosperity. As long as China always insists on the unswerving status of public ownership, and as long as China always sticks to achieving common prosperity, the nature of Chinese socialism will never change. Third, refute the "departure from Mao Zedong Thought". Deng Xiaoping Theory and Mao Zedong Thought are the same theoretical system. Mao Zedong Thought laid the theoretical foundation for Deng Xiaoping's theory. Deng Xiaoping's theory was based on the comprehensive inheritance of Mao Zedong Thought and the theoretical sublimation of China's new practice of reform and opening up. Therefore, those who criticize Deng Xiaoping Theory "departure from Mao Zedong Thought" people, they are ignorant of the history of the Chinese Communist Party.

\section{The realization of Deng Xiaoping's social justice thought}

With the deepening of reform and opening up, inter-regional, urban and rural and inter-class social justice issues become increasingly prominent. Deng Xiaoping's social justice thought not only has important theoretical value, but also has important practical value to solve the problem of social justice. Of course, Deng Xiaoping's social justice is in the process of solving social injustice gradually realized.

\subsection{Developing productivity: material prerequisites for social justice}

The most fundamental idea of Deng Xiaoping's social justice is to develop the productive forces through economic construction as the center, so as to lay a solid material premise for Deng Xiaoping's social justice thought from theory to reality. Of course, since the reform and opening up, Deng Xiaoping has learned from both historical and negative experiences in the development process of new China. He attaches great importance to and always emphasizes the vital role of developing socialist productive forces. For the development of productive forces and the importance of achieving social justice, Deng Xiaoping believes that: "The superiority of socialism, the most fundamental is to greatly develop social productive forces, and gradually improve the people's material and spiritual life" [6]. It can be seen that Deng Xiaoping realized that only by vigorously developing socialist productive forces can we improve the living standards of the broad masses of the people and achieve social justice, so as to further demonstrate the superiority of the socialist system and fundamentally consolidate the socialist system.

\subsection{Institutional construction: system guarantee of social justice}

Deng Xiaoping's social justice thought from the theory to become a reality, it needs a strong system of protection. The system has the characteristics of stability and compulsion, and only by the guarantee of the system, can we ensure the effective implementation of social justice. For the importance of the system, Deng Xiaoping in the "party and state leadership system reform" made a brilliant interpretation: "The system of leadership and organization is more fundamental, holistic, stable and long-term, and this kind of institutional problem is related to whether the party and the state change the color, which 
must cause the whole party to attach great importance" [7]. It can be seen that Deng Xiaoping highly emphasized the important role of the system in the socialist modernization drive. Of course, the realization of Deng Xiaoping's social justice thought requires the full protection of the fundamental, the overall situation, the stability and the long-term system.

\subsection{Cultivating citizen consciousness: the only way of social justice}

We should cultivate the awareness of citizens to achieve the ultimate goal of Deng Xiaoping's social justice thought. As we all know, human society has long been the pursuit of democracy and the rule of law, freedom and equality, fairness and justice as the ultimate value. Establishing the concept of fairness and justice plays an important role in strengthening civic awareness education. The idea of setting up the socialist justice is to cultivate the citizens to participate in the economic, political and social life, and gradually form an environment of opportunity justice, distributive justice, procedural justice and result justice, so as to properly deal with the interests and contradictions among the different classes, and finally make the social equity and justice become the habit of citizen's thought and life. In addition, in the process of strengthening the education of citizen consciousness, the mass media plays a vital role. Therefore, we should make full use of the role of mass media such as television, radio, newspapers, networks and various new media in the cultivation of civic consciousness, so that fairness and justice can really penetrate into the hearts of the broad masses of the people.

\section{Conclusion}

In this paper, we have carried on the innovation in the system and the viewpoint. Although Deng Xiaoping's social justice thought has important theoretical significance and application value, the current research is still confined to Deng Xiaoping's social justice thought of a key point to discuss, which is short of systematic and comprehensive. Of course, with the advancement of socialist modernization, people are increasingly aware of the importance of social justice. There is no doubt that Deng Xiaoping's thought of social justice has a particularly important and urgent theoretical and practical value. In addition, the shortcomings of this paper are mainly limited to theoretical research. Because social justice is a realistic problem about people's livelihood, this paper lacks the content of empirical research.

\section{References}

[1]. Callahan W A. History, Tradition and the China Dream: socialist modernization in the World of Great Harmony [J]. Journal of Contemporary China, 2015, 24(96): 983-1001.

[2]. Dai E. China's inclusive development strategy and its effect on regional disparity [J]. Journal of Chinese Economic and Business Studies, 2016, 14(3): 263-278.

[3]. Hofman P S, Moon J, Wu B. Corporate social responsibility under authoritarian capitalism dynamics and prospects of state-led and society-driven CSR[J]. Business \& Society, 2015: 57.

[4]. Li L I U. Analysis on Problems and Countermeasures of the Development of Chinese Philanthropy from the View of Culture: Also on the Diversified Construction of Social Assistance System [J]. Journal of Yunnan Agricultural University (Social Science), 2015, 2: 008.

[5]. Naustdalslid J. Circular economy in China-the environmental dimension of the harmonious society [J]. International Journal of Sustainable Development \& World Ecology, 2014, 21(4): 303-313.

[6]. Ngok K L, Huang G. Policy paradigm shift and the changing role of the state: The development of social policy in China since 2003[J]. Social Policy and Society, 2014, 13(02): 251-261.

[7]. Palmer M. 6. Mediating state and society: social stability and administrative suits[J]. The Politics of Law and Stability in China, 2014: 107. 
[8]. Tao T. People oriented: the values of the people's livelihood of the communist party of China [J]. Journal of Changchun Institute of Technology (Social Sciences Edition), 2015, 2: 004.

[9]. Xiaoping Z, Zhu H, Deng S. Institutional ethical analysis of resident perceptions of tourism in two Chinese villages[J]. Tourism Geographies, 2014, 16(5): 785-798.

[10]. Yongnian Z. between the State and the Market: The Political Logic of Social Policy Reform in China [J]. Social Development and Social Policy:'International Experiences and China"s Reform', 2016: 267.

[11]. Zeng J. The Debate on Regime Legitimacy in China: bridging the wide gulf between Western and Chinese scholarship [J]. Journal of Contemporary China, 2014, 23(88): 612-635. 